\title{
Kontribusi Penerapan Full Day School dan Lingkungan Sekolah terhadap Pembentukan Karakter Siswa
}

\author{
Puja Monika Hasti \\ Pascasarjana Universitas Jambi \\ Email:pujamonikahasti@gmail.com
}

\begin{abstract}
ABSTRAK
Penelitian ini merupakan penelitian survey menggunakan pendekatan kuantitatif. Data dalam penelitian ini diperoleh dengan cara penyebaran angket dan sampel dalam penelitian ini berjumlah 105 responden. Hasil penelitian ini menunjukkan bahwa (a) Penerapan full day school, lingkungan sekolah, dan pembentukan karakter siswa di sekolah dasar (SD) swasta se-kota Sungai Penuh termasuk dalam kategori "Sangat Baik". Dengan rata-rata skor total setiap variabel yaitu, full day school rata-rata skor totalnya sebesar 452,7, lingkungan sekolah rata-rata skor totalnya sebesar 444,5, dan pembentukan karakter rata-rata skor totalnya sebesar 453,4. (b) ada kontribusi positif antara penerapan full day school terhadap pembentukan karakter siswa di sekolah dasar (SD) swasta sekota Sungai Penuh (c) ada kontribusi positif antara lingkungan sekolah terhadap pembentukan karakter siswa di sekolah dasar (SD) swasta se-kota Sungai Penuh (d) ada kontribusi positif sebesar 53\% yang termasuk kategori kontribusi cukup kuat antara penerapan full day school dan lingkungan sekolah secara simultan terhadap pembentukan karakter siswa di sekolah dasar (SD) swasta se-kota Sungai Penuh.
\end{abstract}

Kata Kunci: Full Day School, Lingkungan Sekolah, Karakter Siswa.

\section{ABSTRACT}

This research is a survey research using a quantitative approach. The data in this study were obtained by distributing questionnaires and samples in this study amounted to 105 respondents. The results of this study indicate that (a) The application of full day school, school environment, and character building of students in private elementary schools in Sungai Penuh is included in the "Very Good" category. With the average total score of each variable being, full day school has an average total score of 452.7, an average school environment with a total score of 444.5, and an average total score of 453.4. (b) there is a positive contribution between the application of full day school to the formation of student character in private elementary schools in Sungai Penuh (c) there is a positive contribution between the school environment towards the formation of the character of students in private elementary schools in the city of Sungai Penuh $(d)$ there is a positive contribution of 53\% which is included in the category of quite strong contribution between the implementation of full day school and the school environment simultaneously to the character building of students in private elementary schools in the city of Sungai Penuh.

Keywords: Full Day School, school environment, students character.

(C) Puja Monika Hasti

Under The License CC-BY SA 4.0 


\section{PENDAHULUAN}

Pendidikan adalah upaya mengembangkan daya dan potensi anak secara kognitif, afektif dan psikomotorik sesuai dengan tuntunan kurikulum 2013. Dalam UU RI nomor 20 tahun 2003 tentang sistem pendidikan nasional (pada bab I pasal 1 ayat 1) disebutkan bahwa pendidikan adalah usaha sadar dan terencana untuk mewujudkan suasana belajar dan proses pembelajaran agar peserta didik secara aktif mengembangkan potensi dirinya untuk memiliki kekuatan spiritual keagamaan, pengendalian diri, kepribadian, kecerdasan, akhlak mulia, serta keterampilan yang diperlukan dirinya, masyarakat, bangsa dan negara.

Pada saat ini masalah karakter sangat disorot berbagai pihak, terutama dalam lingkungan pendidikan. Setidaknya ada dua tujuan pendidikan, yaitu membantu anak menjadi cerdas dan membantu menjadi individu yang baik. Semuanya itu berpusat pada pembentukan karakter. Untuk menjadi cerdas anak harus didukung dengan karakter yang kuat dan untuk menjadi individu yang baik pun ia harus memiliki karakter yang baik pula. Demikian pula, kesuksesan atau keberhasilan orangorang sukses dalam hidupnya pun ternyata disebabkan karena karakternya yang kuat dan baik. (Lickona, 2013) menyatakan bahwa kesehatan bangsa kita dalam beberapa abad mendatang bergantung pada bagaimana keseriusan kita semua untuk berkomitmen terhadap pendidikan karakter ini. Seorang filsuf yunani, Heraclitus menyatakan bahwa karakter membentuk takdir seseorang dan takdir tersebut menjadi takdir seluruh masyarakat. Pada karakter warga negara pun terletak kesejahteraan bangsa.

Pendidikan karakter merupakan suatu sistem penanaman nilai-nilai karakter kepada peserta didik yang meliputi komponen: kesadaran, pemahaman kepedulian, dan komitmen yang tinggi untuk melaksanakan nilainilai tersebut, baik terhadap Allah Tuhan Yang Maha Esa, diri sendiri, sesama, lingkungan, maupun masyarakat dan bangsa secara keseluruhan, sehingga menjadi manusia sempurna sesuai dengan kodratnya (Mulyasa: 2016).

Pendidikan karakter yang sedang diterapkan di Indonesia pada saat ini, merupakan suatu solusi yang sangat tepat untuk anak di usia remaja. Pendidikan karakter dilaksanakan dengan menerapkan nilai-nilai Pancasila dalam pendidikan karakter yaitu 5 (lima) nilai utama yang saling berkaitan diantaranya religiusitas, nasionalisme, kemandirian, gotong royong, dan integritas yang terintegrasi dalam kurikulum (PERMENDIKBUD RI nomor 20 tahun 2018 tentang penguatan pendidikan karakter pada satuan pendidikan formal, Pasal 2 Ayat 1). Karakter terbentuk dari kebiasaan yang telah dilakukannya setiap hari dan lingkungan merupakan salah satu faktor yang sangat berkontribusi pada anak di usia remaja. Disini bukan hanya tugas orang tua saja, melainkan guru juga harus berperan untuk mengatasi problematika anak di usia remaja pada saat era modern ini.

Hal ini menjadikan sekolahsekolah dalam tingkat SD, SMP dan SMA bersaing untuk menciptakan sistem pendidikan yang dianggap mampu menjadikan peserta didik yang berkarakter, dapat maju, berkembang, bersaing dan mampu bertahan hidup dalam era globalisasialah satunya adalah sistem full day school. Menurut (Arifin, 2012) menjelaskan bahwa sistem full day school merupakan ciri khas sekolah terpadu- yang pembelajaran dengan sistem full day school mengharuskan sekolah merancang perencanaan 
pembelajaran dari pagi hingga sore. Sistem pengajaran dalam full day school yang berlangsung selama sehari penuh, mengemas seluruh program pembelajaran dan kegiatan siswa disekolah dalam sebuah sistem pendidikan yang bernuansa Islam dengan memberikan waktu tambahan untuk siswa mendalami pelajaran keagamaan. Full day school merupakan model sekolah umum yang memadukan sistem pengajaran agama secara intensif yaitu dengan memberi tambahan waktu khusus untuk pendalaman keagamaan siswa. Sehingga pembelajaran dengan sistem full day school bertujuan untuk mengembangkan potensi, minat, bakat dan kreativitas anak dengan mencakup aspek kognitif, afektif, dan psikomotorik melalui kegiatan intrakurikuler dan ekstrakulikuler yang diadakan oleh sekolah.

Pelaksanaan full day school merupakan salah satu alternatif untuk mengatasi berbagai masalah pendidikan, baik dalam prestasi maupun dalam hal moral atau akhlak. Dengan mengikuti full day school, orang tua dapat mencegah dan menetralisir kemungkinan siswa terlibat dalam kegiatan-kegiatan non akademis yang menjerumus pada kegiatan yang negatif.

Usia anak-anak adalah usia yang paling kritis atau paling menentukan dalam pembentukan karakter dan kepribadian seseorang termasuk juga intelegensi hampir seluruhnya terjadi pada usia anak-anak. Karena itu, pendidikan yang menanamkan nilai-nilai luhur kemanusiaan (pengembangan intelegensi, karakter, kreativitas, moral dan kasih sayang) sangatlah perlu diberikan pada anak usia dini.

Kegiatan yang biasa di terapkan di sekolah full day school yang dapat membantu pembentukan karakter siswa yaitu shalat berjama'ah shalat dhuha dan zhuhur, bersalaman dan mengucapkan salam kepada Bapak/Ibu guru sebelum masuk kelas, selanjutnya tahfidz Alqur'an, membaca doa belajar dan pembuka hati pembelajaran bahasa Arab dan Inggris, serta kegiatan ekstrakulikuler (Pramuka, tari, silat, futsal, badminton, dan kegiatan lain sesuai minat dan bakat siswa) dapat membantu pembentukan karakter siswa. Full day school dilaksanakan senin sampai jum'at. Dalam PERMENDIKBUD RI Nomor 23 Tahun 2017 tentang hari sekolah (Pasal 2 Ayat 1) hari Sekolah dilaksanakan 8 (delapan) jam dalam 1 (satu) hari atau 40 (empat puluh) jam selama 5 (lima) hari dalam 1 (satu) minggu. Pembelajaran full day school sebagai bentuk alternatif dalam upaya memperbaiki manajemen pendidikan, khususnya dalam manajemen pembelajaran, juga merupakan tuntunan kebutuhan masyarakat yang menghendaki anak dapat belajar dengan baik di sekolah dengan waktu belajar lebih lama. Pendidikan dengan penekanannya pada kegiatan pembelajaran. yaitu dengan penambahan waktu belajar siswa dari pagi sampai sore. Profesionalisme dalam pendidikan memang harus diterapkan para pendidik, sehingga dapat membangkitkan minat dan kemauan peserta didik untuk belajar, memahami cara belajar, dan senang dalam belajar. Penekanan pendidikan adalah pada kegiatan pembelajaran dan siswa merupakan objek belajar, oleh karena itu kegiatan pembelajaran terfokus pada pemberdayaan siswa (Student learning).

Kurikulum yang diterapkan di sekolah dasar swasta yaitu Sekolah Dasar Islam Terpadu Amanah Sungai Penuh, Sekolah Dasar Islam Mutiara Al Madani Sungai Penuh, dan Sekolah Dasar Islam Terpadu Al Fikri Sungai Penuh, diistilahkan sebagai kurikulum berbasis keterpaduan. Kurikulum ini 
menggabungkan dua kurikulum kementerian pendidikan dan kebudayaan dan kurikulum kementerian agama, sehingga beban kurikulumnya lebih banyak dan membutuhkan waktu yang banyak juga. Sementara di lapangannya, siswa dituntut untuk menguasai keduanya. Karena membutuhkan waktu yang banyak maka Sekolah Dasar Islam Terpadu Amanah Sungai Penuh, Sekolah Dasar Islam Mutiara Al Madani Sungai Penuh, dan Sekolah Dasar Islam Terpadu Al Fikri Sungai Penuh, menerapkan sistem full day school dalam pembelajarannya.

\begin{tabular}{lcr}
\multicolumn{2}{c}{ Selain itu, faktor yang juga } \\
memberi & kontribusi & terhadap \\
pembentukan & karakter & adalah
\end{tabular} lingkungan sekolah. Pembentukan karakter di sekolah sangat diperlukan, karena anak memiliki waktu yang cukup banyak untuk berada di lingkungan sekolah dan hal itu memberi peranan penting bagi perkembangan belajar para siswa dalam pembentukan karakternya. Lingkungan sekolah meliputi lingkungan fisik sekolah seperti lingkungan sekitaran sekolah, sarana dan prasarana belajar yang ada, sumbersumber belajar, media belajar, dan sebagainya. Lingkungan sosial yang menyangkut hubungan siswa dengan teman-temannya, guru-gurunya serta staf sekolah yang lain. Lingkungan sekolah juga menyangkut lingkungan akademis, yaitu suasana dan pelaksanaan kegiatan belajar mengajar, berbagai kegiatan kokurikuler, dan sebagainya (Sukmadinata: 2011).

Kontribusi lingkungan sekolah terhadap karakter siswa di sekolah cukup besar, karena sekolah adalah lingkungan sosial kedua setelah keluarga yang akan dikenal oleh siswa. Lingkungan sekolah mempunyai faktor yang dapat berkontribusii pembentukan karakter siswa, diantaranya yang perlu diperhatikan adalah kematangan siswa, keadaan fisik siswa, kehidupan sekolah, guru, staf, kurikulum dan metode yang digunakan dalam mengajar. Dalam lingkungan sekolah, siswa merupakan subjek dan objek yang memerlukan bimbingan dari orang lain untuk mengarahkan potensi yang dimilikinya serta bimbingannya menuju kedewasaan yang berkarakter. Dengan pembentukan karakter secara terus menerus diharapkan dapat membentuk siswa yang berkarakter dan berakhlakul karimah. Siswa yang mempunyai karakter yang baik akan mampu mewujudkan norma-norma dan nilai positif yang akan berkontribusii keberhasilannya dalam pendidikan. Lingkungan sekolah tidak hanya pendidikan saja yang diajarkan tetapi juga nilai-nilai moral dan etika dalam berperilaku. Bisa saja ketika anak belum sekolah perilakunya kurang baik dan setelah masuk ke sekolah menjadi baik atau sebaliknya ketika anak belum masuk sekolah sudah mempunyai potensi akhlak yang baik tetapi ketika masuk sekolah, akhlak atau perilakunya berubah menjadi kurang baik karena disebabkan anak tersebut terpengaruh dari komponen-komponen yang ada di sekolah tidak sesuai dengan apa yang ingin dicapai anak.

Ketertarikan peneliti dalam melakukan penelitian ini adalah pertama, masih banyaknya lembaga pendidikan yang belum dapat mencetak generasi yang memiliki karakter yang baik hal tersebut dapat dilihat bahwa masih ada peserta didik membuang sampah sembarangan, bersikap tidak sopan, berkata kasar serta perilaku-perilaku yang kurang baik. Kedua, lembaga pendidikan yang masih memiliki perhatian terhadap kemerosotan moral dan kesan-kesan karakter yang ada pada peserta didik dengan mengadakan penambahan jam pelajaran melalui sistem full day school dalam 
pembentukan karakter siswa mulai dari dini. Ketiga, keresahan masyarakat terhadap perilaku generasi bangsa yang semakin hari tidak menunjukkan akhlak maupun karakter yang baik, sehingga lembaga-lembaga pendidikan terutama di Sekolah Dasar menjadi awal dari pembentukan karakter dan pencegah kemerosotan moral mulai dari usia dini. Moralitas merupakan faktor yang esensial. Oleh karena itu, dapat dibayangkan betapa rusaknya generasi bangsa manakala moralitas atau karakter yang dimiliki generasi saat ini mulai menurun. Dengan demikian diperlukan upaya-upaya pembentukan karakter mulai sejak dini agar kelak anak dapat mengetahui mana perilaku yang baik dan perilaku yang buruk. Dalam upaya pembentukan karakter di sekolah tidak lepas dari yang namanya guru, seorang guru harus mempunyai kompetensi keguruan yaitu kompetensi pedagogik, pribadi, sosial, dan profesional. Apabila guru menguasai empat kompetensi tersebut, kemungkinan besar dapat membentuk karakter yang baik terhadap siswanya.

Adapun tujuan penelitian ini adalah: (a) untuk mengetahui gambaran penerapan full day school, lingkungan sekolah, dan pembentukan karakter siswa di sekolah dasar swasta se-kota Sungai Penuh (b) untuk mengetahui kontribusi penerapan full day school terhadap karakter siswa di sekolah dasar swasta se-kota Sungai Penuh (c) untuk mengetahui kontribusi lingkungan sekolah terhadap karakter siswa di sekolah dasar swasta se-kota Sungai Penuh (d) untuk mengetahui kontribusi penerapan full day school dan lingkungan sekolah terhadap pembentukan karakter siswa di sekolah dasar swasta se-kota Sungai Penuh. Hipotesis yang akan diuji dan dibuktikan dalam penelitian ini berkaitan dengan adanya kontribusi variabel bebas.
Pengujian hipotesis yang dilakukan adalah pengujian hipotesis alternative (Ha) menyatakan ada kontribusi positif variabel independen terhadap variabel dependen yaitu: (a) Ha: Ada kontribusi positif antara penerapan full day school terhadap karakter siswa sekolah dasar (SD) swasta se-kota Sungai Penuh (b) $\mathrm{Ha}_{2}$ : Ada kontribusi positif antara lingkungan sekolah terhadap karakter siswa sekolah dasar (SD) swasta se-kota Sungai Penuh. (c) Ha3: Ada kontribusi positif secara simultan antara penerapan full day school dan lingkungan sekolah terhadap pembentukan karakter siswa sekolah dasar (SD) swasta se-kota Sungai Penuh. Artikel ini menguraikan tentang kontribusi penerapan full day school dan lingkungan sekolah terhadap pembentukan karakter siswa di Sekolah Dasar Swasta Se-Kota Sungai Penuh.

\section{METODE PENELITIAN}

Penelitian ini merupakan penelitian survey dengan pendekatan kuantitatif. Menurut Creswell (2012) ciri pendekatan kuantitatif adalah menggambarkan masalah penelitian melalui pemaparan untuk menjelaskan hubungan antar variable). Sedangkan metode survey adalah suatu cara melakukan pengamatan dimana indikator mengenai variable adalah jawaban-jawaban terhadap pertanyaan yang diberikan kepada responden baik secara lisan maupun tulisan.

\section{Populasi Penelitian}

Populasi penelitian merupakan keseluruhan dari objek penelitian yang dapat berupa manusia, hewan, tumbuhtumbuhan, udara, gejala, nilai, peristiwa, sikap hidup, dan sebagainya, sehingga objek-objek ini dapat menjadi sumber data penelitian (Burhan Bungin: 2013). Populasi dalam penelitian ini adalah seluruh siswa Sekolah Dasar Swasta SeKota Sungai Penuh yang menerapkan 
full day school. Berkaitan dengan hal full day school, maka populasi dalam penelitian ini ada tiga (3) Sekolah dasar swasta yaitu SD IT Amanah Sungai Penuh, SD Islam Mutiara Al Madani Sungai Penuh dan SD IT Al Fikri Sungai Penuh. Jumlah populasi sebanyak 1067 Siswa yang tersebar di Sekolah Dasar (SD) Swasta se-Kota Sungai Penuh.

\section{Sampel Penelitian}

Sampel adalah bagian dari populasi yang mempunyai ciri-ciri atau keadaan tertentu yang akan diteliti (Sugiyono: 2017). Sampel dapat didefinisikan sebagai anggota populasi yang dipilih dengan menggunakan prosedur tertentu sehingga diharapkan dapat mewakili populasi (Martono: 2012).

Sampel dalam penelitian ini adalah seluruh siswa kelas V Sekolah Dasar Swasta Se-kota Sungai Penuh yang menerapkan full day school. Alasan memilih siswa kelas V SD sebagai subjek penelitian adalah untuk mengurangi resiko non-sampling error terutama yang berasal dari responden. error tersebut diantaranya, sulit mendapatkan jawaban yang sebenarnya karena siswa lebih terfokus menghadapi UAN dan UAS (pada siswa kelas VI), serta kekurang-mampuan siswa memahami maksud pertanyaanpertanyaan dalam angket (pada siswa kelas I s.d. kelas IV). Jumlah sampel dalam penelitian ini dari tiga (3) sekolah dasar swasta se-kota Sungai Penuh yang diambil dari siswa kelas V SD adalah sebanyak 149 Siswa.

\section{Metode Pengumpulan Data}

Instrumen yang digunakan pada penelitian ini adalah kuesioner. Kuesioner merupakan teknik pengumpulan data yang dilakukan dengan cara memberi seperangakat pertanyaan atau pernyataan tertulis kepada responden untuk dijawabnya (Sugiyono: 2017). Bentuk kuesioner dalam penelitian ini yaitu berisi daftar pernyataan yang mengharapkan responden untuk memilih salah satu alternatif jawaban dari setiap pernyataan yang telah disediakan. Skala pengukuran dalam penelitian ini menggunakan skala likert (Selalu, Sering, Kadang-kadang, Jarang, Tidak Pernah). Adapun indikator dari setiap variabel yaitu:

Table 1. Indikator Setiap Variabel

$\begin{array}{ccc}\text { Indikator } & \text { Indikator } & \text { Indikator } \\ \text { Full Day School }\left(\mathrm{X}_{1}\right) & \text { Lingkungan Sekolah }\left(\mathrm{X}_{2}\right) & \text { Karakter Siswa }\end{array}$

(Y)

a. Kegiatan pembelajaran a.Hubungan guru dengan siswa a. Religiusitas

b. Kegiatan keagamaan b.Hubungan siswa dengan siswa b.Nasionalisme

c. Kepribadian siswa c. Metode pembelajaran c.Kemandirian

\begin{tabular}{lll}
\hline d. Ekstrakurikuler & d.Disiplin sekolah & d.Gotong Royong
\end{tabular}

e. Kebiasaan (sikap, pola, e.Sarana dan prasarana sekolah e.Integritas dan tingkah laku siswa)

Dalam penelitian ini uji instrumen yang digunakan yaitu uji validitas dan uji reliabilitas. Teknik analisis data dalam penelitian ini meliputi (a). teknik analisis deskriptif, (b) uji persyaratan/asumsi yaitu diuji normalitas sebaran datanya, uji linieritas kontribusinya, uji heteroskedastisitas (uji homogenitas), dan uji multikolinieritas untuk menguji independensi antar variabel bebas, (c). analisis regresi berganda, (d). uji 
hipotesis yaitu uji t dan uji f, (e). koefisien determinasi.

\section{HASIL PENELITIAN}

\section{Gambaran Penerapan Full Day School}

Secara keseluruhan berdasarkan angket yang telah peneliti olah sebagaimana dilihat dari hasil kuesioner yang diisi oleh responden (siswa) kelas V di sekolah Dasar (SD) Swasta se-kota Sungai Penuh dengan jumlah total 105 orang responden tergolong dalam kategori Sangat Baik. Hal ini bisa diasumsikan bahwa sistem full day school sudah diterapkan dengan sangat baik.

Menurut Suyyinah (2019) full day school bertujuan sebagai salah satu upaya pembentukan akidah dan akhlak siswa dan menanamkan nilai-nilai positif. Full day school juga memberikan dasar yang kuat dalam belajar pada segala aspek yaitu perkembangan intelektual, fisik, sosial dan emosional. Selanjutnya penelitian ini juga sejalan dengan yang dikemukakan oleh peneliti lain yaitu Raharjo, Yunita, ddk (2018) bahwa pelaksanaan full day school di SD Nasima termasuk dalam kategori baik. Sagala (2013) menyatakan bahwa, pembelajaran full day school dapat membuat waktu anak banyak terlibat dalam kelas yang bermuara pada produktifitas yang tinggi dan juga menunjukkan sikap yang lebih positif serta terhindar dari penyimpanganpenyimpangan karena keseharian para siswa dihabiskan di sekolah dan dalam pengawasan guru

\section{Dalam Permendikbud RI} Nomor 23 Tahun 2017 tentang hari sekolah pada Pasal 2 yaitu: a). Hari Sekolah dilaksanakan 8 (delapan) jam dalam 1 (satu) hari atau 40 (empat puluh) jam selama 5 (lima) hari dalam 1 (satu) minggu. b). Ketentuan 8 (delapan) jam dalam 1 (satu) hari atau 40 (empat puluh) jam selama 5 (lima) hari dalam 1 (satu) minggu sebagaimana dimaksud pada ayat (1), termasuk waktu istirahat selama 0,5 (nol koma lima) jam dalam 1 (satu) hari atau 2,5 (dua koma lima) jam selama 5 (lima) hari dalam 1 (satu) minggu. c) Dalam hal diperlukan penambahan waktu istirahat sebagaimana dimaksud pada ayat (2), Sekolah dapat menambah waktu istirahat melebihi dari 0,5 (nol koma lima) jam dalam 1 (satu) hari atau 2,5 (dua koma lima) jam selama 5 (lima) hari dalam 1 (satu) minggu. d). Penambahan waktu istirahat sebagaimana dimaksud pada ayat (3) tidak termasuk dalam perhitungan jam sebagaimana dimaksud pada ayat (1).

Berdasarkan temuan ini peneliti menyatakan bahwa diperkaya dengan analisis pembahasan instrument dari indikator full day school terlihat dari 5 indikator dan 13 item pernyataan yang diajukan kepada responden dengan ratarata skor total yaitu sebesar 452,7. Jadi, peneliti menyimpulkan bahwa penerapan Full Day School di sekolah dasar (SD) swasta se-kota Sungai Penuh termasuk kategori "Sangat Baik". Hal ini terlihat dari kegiatan pembelajaran siswa, kegiatan keagamaan , ekstrakurikuler dan kegiatan lainya di sekolah Dasar (SD) Swasta se-kota Sungai Penuh yang berjalan efektif dari mulai jam masuk sekolah 07.00 sampai jam15.00 pulang sekolah.

\section{Gambaran Lingkungan Sekolah}

Dari hasil penelitian di lapangan berdasarkan pernyataan yang peneliti sampaikan bahwa kualitas lingkungan sekolah di sekolah Dasar (SD) Swasta se-kota Sungai Penuh masuk dalam kategori sangat baik. Hal ini berarti dengan adanya lingkungan sekolah yang baik di sekolah Dasar (SD) Swasta sekota Sungai Penuh dapat berkontribusi terhadap pembentukan karakter siswa di sekolah menjadi lebih baik. 
Menurut Sukmadinata (2011) lingkungan sekolah terdiri dari: a). Lingkungan fisik sekolah seperti sarana dan prasarana belajar, sumber-sumber belajar, dan media belajar. b). Lingkungan sosial menyangkut hubungan siswa dengan teman-temanya, guru-gurunya, dan staf sekolah yang lain. c).Lingkungan Akademis yaitu suasana sekolah dan pelaksanaan kegiatan belajar mengajar \& berbagai kegiatan kokurikuler. Pendidikan karakter merupakan upaya pembentukkan karakter yang dikontribusi oleh lingkungan. Hal ini selaras dengan pernyataan Ramdhani (2014) yang mengungkapkan bahwa karakter sebagai nilai dasar yang membangun pribadi seseorang, terbentuk baik karena pengaruh hereditas maupun pengaruh lingkungan, yang membedakan dengan orang lain, serta diwujudkan dalam sikap dan perilakunya dalam kehidupan seharihari.

Berdasarkan temuan ini peneliti menyatakan bahwa diperkaya dengan analisis pembahasan instrument dari indikator lingkungan sekolah terlihat dari 5 indikator dan 15 item pernyataan yang diajukan kepada responden dengan rata-rata skor total yaitu sebesar 444,5. Jadi, peneliti menyimpulkan bahwa kualitas lingkungan sekolah dasar (SD) swasta se-kota Sungai Penuh termasuk kategori "Sangat Baik". Hal ini terlihat dari hubungan guru dengan guru, hubungan siswa dengan siswa, metode belajar, disiplin sekolah baik dan dapat membuat siswa merasa nyaman berada di lingkungan sekolah.

\section{Gambaran Karakater Siswa}

Karakter siswa di sekolah dasar (SD) swasta se-kota Sungai Penuh berdasarkan temuan penelitian bahwa dikategorikan masuk dalam kategori sangat baik. Hal ini sejalan dengan temuan yang dikemukakan oleh peneliti lain yaitu yaitu Raharjo, Yunita, ddk (2018) hasil penelitiannya menunjukkan bahwa karakter religius siswa kelas $\mathrm{V}$ SD Nasima Semarang secara umum juga dalam kategori baik yaitu sebesar $72 \%$.

Pendidikan karakter yaitu upaya yang disengaja untuk memupuk kebajikan(sifat yang baik) secara objektif, baik secara individu tetapi seluruh masyarakat (Lickona: 2013). Lebih lanjut Lickona mengungkapkan bahwa karakter berkaitan dengan konsep moral, sikap moral dan perilaku moral. Setiap individu telah membekali diri mereka dengan karakter, baik itu karakter atau moral yang baik, atau sebaliknya. Dalam hal ini, sebagai layanan pendidikan, sekolah memfasilitasi kegiatan-kegiatan untuk mengembangkan karakter ataupun menumbuhkan karakter pada siswa. Untuk memfasilitasi pengembangan pendidikan karakter, Kemendikbud mencanangkan kebijakan lima hari sekolah. Dalam PP RI nomor 87 tahun 2017 tentang penguatan pendidikan karakter pada Pasal 2, menyakatakan bahwa penguatan pendidikan karakter PPK memiliki tujuan: (a). Membangun dan membekali Peserta Didik sebagai generasi emas Indonesia Tahun 2045 dengan jiwa Pancasila dan pendidikan karakter yang baik guna menghadapi dinamika perubahan di masa depan; (b). Mengembangkan platform pendidikan nasional yang meletakkan pendidikan karakter sebagai jiwa utama dalam penyelenggaraan pendidikan bagi Peserta Didik dengan dukungan pelibatan publik yang dilakukan melalui pendidikan jalur formal, nonformal, dan informal dengan memperhatikan keberagaman budaya Indonesia; dan (c). Merevitalisasi dan memperkuat potensi dan kompetensi pendidik, tenaga kependidikan, Peserta Didik, masyarakat, dan lingkungan keluarga dalam mengimplementasikan PPK. 
\begin{tabular}{lll}
\multicolumn{3}{c}{ Menurut Ramdhani (2014) } \\
menyatakan bahwa prinsip yang \\
digunakan dalam pengembangan \\
pendidikan karakter adalah: (a).
\end{tabular} Berkelanjutan, mengandung makna bahwa proses pengembangan nilai-nilai karakter merupakan proses yang tiada henti, dimulai dari awal peserta didik sampai selesai dari suatu satuan pendidikan, bahkan sampai terjun ke masyarakat; (b). Melalui semua mata pelajaran, pengembangan diri dan budaya sekolah, serta muatan lokal; (c). Nilai tidak sekedar diajarkan, tetapi dikembangkan dan dilaksanakan. Aktivitas belajar dilakukan untuk mengembangkan seluruh kemampuan ranah kognitif, afektif, dan psikomotorik; dan (d). Proses pendidikan dilakukan peserta didik secara aktif dan menyenangkan.

Berdasarkan temuan ini peneliti menyatakan bahwa diperkaya dengan analisis pembahasan instrument dari indikator karakter siswa terlihat dari 5 indikator dan 14 item pernyataan yang diajukan kepada responden dengan ratarata skor total yaitu sebesar 453,4. Jadi, peneliti menyimpulkan bahwa karakter siswa di sekolah dasar (SD) swasta sekota Sungai Penuh termasuk kategori "Sangat Baik". Hal ini terlihat dari sikap religiustas siswa, nasionalisme, kemandirian siswa, gotong royong dan integritas siswa menjadi baik sehingga sangat diperlukan sistem dan lingkungan sekolah yang baik untuk mendukungnya. Uji Persyratan Analisis/ Uji Asumsi Pertama, uji normalitas digunakan untuk melihat apakah model regresi variabel dependen dan independen memiliki distribusi normal atau tidak. Model regresi yang baik adalah distribusi data normal atau mendekati normal.

\section{Grafik 1. Uji Normalitas}

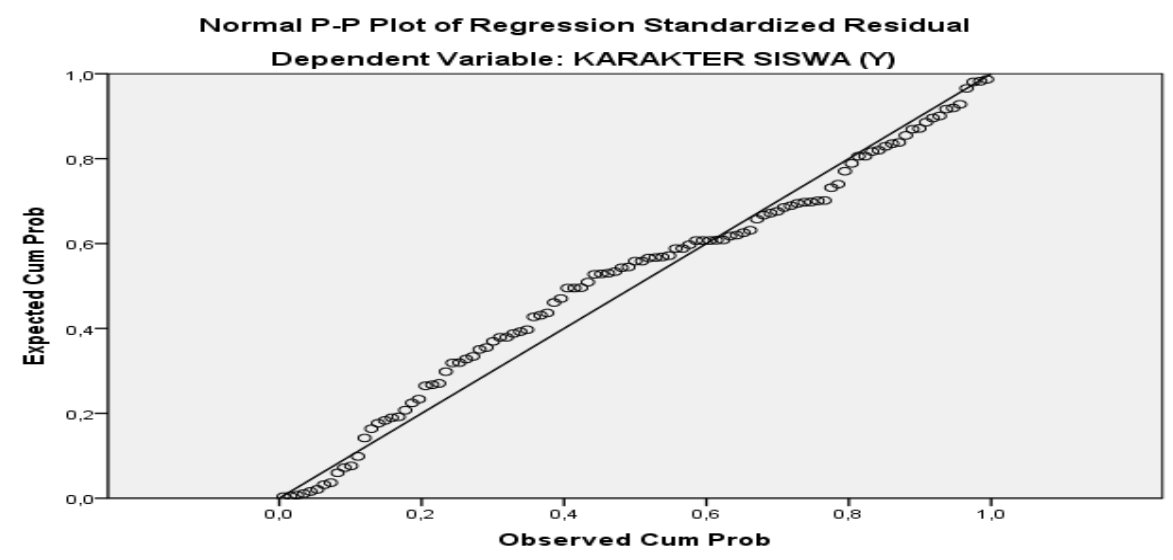

Berdasarakan grafik uji normalitas, dapat dilihat penyebaran data plotingnya (titik-titik) menggambarkan semua mengikuti garis diagonal, maka hal ini menunjukkan model regresi berdistribusi normal.
Kedua, uji linieritas berfungsi untuk mengetahui bagaimana bentuk hubungan antara variabel bebas dengan variabel terikat.

Tabel 2. Hasil Uji Linieritas Full Day School (X) dan Karakter Siswa (Y)

\begin{tabular}{|c|c|c|c|c|c|c|c|}
\hline \multicolumn{8}{|c|}{ ANOVA Table } \\
\hline & & & $\begin{array}{l}\text { Sum of } \\
\text { Squares }\end{array}$ & $\mathrm{df}$ & $\begin{array}{l}\text { Mean } \\
\text { Square }\end{array}$ & $\mathrm{F}$ & Sig. \\
\hline KARAKTER & Between Groups & (Combined) & 2226,880 & 25 & 89,075 & 5,295 & ,000 \\
\hline SISWA (Y) * & & Linearity & 1543,333 & 1 & 1543,333 & 91,735 & ,000 \\
\hline
\end{tabular}


HaL. 74-90

\begin{tabular}{|c|c|c|c|c|c|c|c|}
\hline \multirow[t]{3}{*}{$\begin{array}{l}\text { FULL DAY } \\
\text { SCHOOL } \\
\text { (X1) }\end{array}$} & & $\begin{array}{l}\text { Deviation } \\
\text { from } \\
\text { Linearity }\end{array}$ & 683,546 & 24 & 28,481 & 1,693 & ,043 \\
\hline & Within Groups & & 1329,082 & 79 & 16,824 & & \\
\hline & Total & & 3555,962 & 104 & & & \\
\hline
\end{tabular}

Tabel 3. Hasil Uji Linieritas Lingkungan Sekolah $\left(\mathbf{X}_{2}\right)$ dan Karakter Siswa (Y)

\begin{tabular}{|c|c|c|c|c|c|c|c|}
\hline \multicolumn{8}{|c|}{ ANOVA Table } \\
\hline & & & $\begin{array}{l}\text { Sum of } \\
\text { Squares }\end{array}$ & df & $\begin{array}{l}\text { Mean } \\
\text { Square }\end{array}$ & $\mathrm{F}$ & Sig. \\
\hline \multirow{5}{*}{$\begin{array}{l}\text { KARAKTER } \\
\text { SISWA (Y) * } \\
\text { LINGKUNGAN } \\
\text { SEKOLAH (X2) }\end{array}$} & \multirow[t]{3}{*}{ Between Groups } & (Combined) & 2331,563 & 26 & 89,676 & 5,713 & ,000 \\
\hline & & Linearity & 1734,559 & 1 & 1734,559 & $\begin{array}{r}110,50 \\
0\end{array}$ & ,000 \\
\hline & & $\begin{array}{l}\text { Deviation } \\
\text { from } \\
\text { Linearity }\end{array}$ & 597,004 & 25 & 23,880 & 1,521 & ,083 \\
\hline & Within Groups & & 1224,398 & 78 & 15,697 & & \\
\hline & Total & & 3555,962 & 104 & & & \\
\hline
\end{tabular}

Berdasarkan ANOVA tabel di atas, diperoleh nilai sig. linearity sebesar 0,00 . Jadi dapat dikatakan nilai sig. linearity $0,00<0,05$. Maka data tersebut berdistribusi linier dan model dapat diterima.
Ketiga, uji heteroskedastisitas dilakukan untuk mengetahui apakah antar variabel independen mempunyai kontribusi yang signifikan dengan nilai residualnya

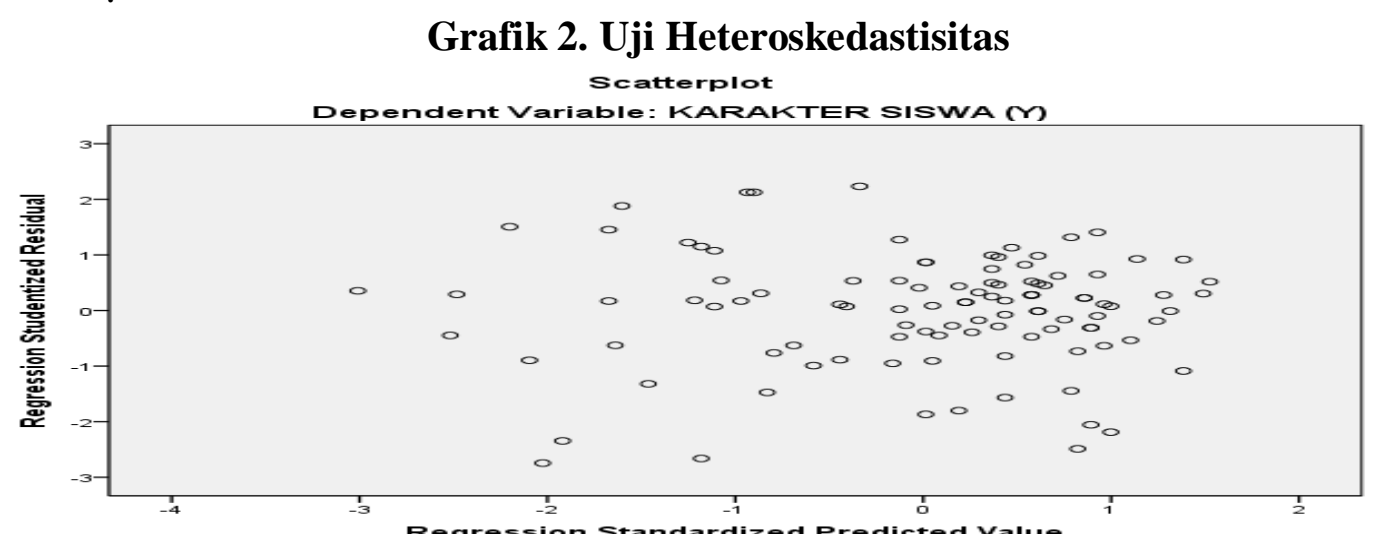

Berdasarkan heteroskedastisitas, heteroskedastisitas scatterplot dapat dilihat bahwa sebaran data tidak membentuk pola yang jelas, titik-titik data menyebar di atas dan di bawah angka 0 pada sumbu Y. Jadi dapat dikatakan bahwa pada model regresi tidak terjadi heteroskedastisitas, dengan kata lain pada model regresi terjadi kesamaan varians dari residual satu pengamatan ke pengamatan yang lain, hal ini menunjukkan bahwa variasi data homogen.

Keempat, multikolinieritas dapat diketahui melalui suatu uji yang dapat mendeteksi dan menguji apakah persamaan yang dibentuk terjadi gejala multikolinieritas, dengan menggunakan atau korelasi diantara variabel bebas. 
Table 4. Multikolinieritas

\begin{tabular}{|c|c|c|c|c|c|c|c|c|}
\hline \multicolumn{9}{|c|}{ Coefficients } \\
\hline \multirow{2}{*}{\multicolumn{2}{|c|}{ Model }} & \multicolumn{2}{|c|}{$\begin{array}{c}\text { Unstandardized } \\
\text { Coefficients }\end{array}$} & \multirow{2}{*}{$\begin{array}{c}\begin{array}{c}\text { Standardized } \\
\text { Coefficients }\end{array} \\
\text { Beta }\end{array}$} & \multirow[t]{2}{*}{$\mathrm{t}$} & \multirow[t]{2}{*}{ Sig. } & \multicolumn{2}{|c|}{ Collinearity Statistics } \\
\hline & & $\mathrm{B}$ & $\begin{array}{l}\text { Std. } \\
\text { Error }\end{array}$ & & & & Tolerance & VIF \\
\hline \multirow[t]{3}{*}{1} & (Constant) & 15,180 & 4,255 & & 3,568 & ,001 & & \\
\hline & $\begin{array}{l}\text { Full Day School } \\
\text { (X1) }\end{array}$ & ,299 & ,099 & 309 & 3,013 & ,003 & ,439 & 2,280 \\
\hline & $\begin{array}{l}\text { Lingkungan } \\
\text { Sekolah (X2) }\end{array}$ & ,449 & ,099 & ,467 & 4,554 & ,000 & ,439 & 2,280 \\
\hline
\end{tabular}

a. Dependent Variable: KARAKTER SISWA (Y)

Berdasarkan tabel Coefficients di atas, dapat dilihat bahwa angka tolerance dari variabel bebas mempunyai nilai tolerance lebih dari $10 \%(0,1)$ yaitu sebesar 0,439>0,1. Dan nilai Variance Inflantion Factor (VIF) kurang dari 10 yaitu sebesar 2,280 < 10. Dengan demikian dapat disimpulkan bahwa dalam model regresi tidak terjadi multikolinieritas antar variabel bebasnya.

\section{Regresi Berganda}

Analisis ini digunakan sebagai suatu alat analisis peramalan nilai kontribusi dari masing-masing variabel bebas terhadap variabel terikat (karakter siswa) untuk membuktikan ada atau tidaknya hubungan fungsi atau hubungan kausal antara dua variabel bebas atau lebih dengan satu variabel terikat (Y).

\section{Table 5. Coefficients}

\begin{tabular}{|c|c|c|c|c|c|c|}
\hline \multicolumn{7}{|c|}{ Coefficients $^{\mathbf{a}}$} \\
\hline \multirow{2}{*}{\multicolumn{2}{|c|}{ Model }} & \multicolumn{2}{|c|}{$\begin{array}{l}\text { Unstandardized } \\
\text { Coefficients }\end{array}$} & \multirow{2}{*}{$\begin{array}{c}\text { Standardized } \\
\text { Coefficients } \\
\text { Beta }\end{array}$} & \multirow[t]{2}{*}{$\mathrm{t}$} & \multirow[t]{2}{*}{ Sig. } \\
\hline & & B & Std. Error & & & \\
\hline \multirow[t]{3}{*}{1} & (Constant) & 15,180 & 4,255 & & 3,568 &, 001 \\
\hline & Full Day School (X1) & ,299 & ,099 &, 309 & 3,013 & ,003 \\
\hline & Lingkungan Sekolah (X2) & ,449 & ,099 & ,467 & 4,554 & ,000 \\
\hline
\end{tabular}

a. Dependent Variable: Karakter Siswa (Y)

Dari tabel Coefficients di atas, dapat diketahui bahwa bilangan constan sebesar 15,180, artinya jika tidak ada full day school dan lingkungan sekolah maka karakter siswa sebesar $15,18 \%$. Nilai koefisien regresi full day school $\left(\mathrm{b}_{1}\right)$ yaitu sebesar 0,299, dan nilai koefisien lingkungan sekolah $\left(b_{2}\right)$ sebesar 0,449 . Jadi dapat diperoleh persamaan regresi berganda pada penelitian ini yaitu sebagai berikut:

$$
\begin{gathered}
Y=a+b_{1} X_{1}+b_{2} X_{2} \\
Y=15,180+0,299 X_{1}+0,449 X_{2}
\end{gathered}
$$

Dari model regresi berganda di atas menunjukkan bahwa setiap kenaikan $1 \%$ penerapan full day school akan meningkatkan karakter siswa sebesar 0,299\%. Dan sebaliknya jika penerapan full day school turun sebesar $1 \%$, maka pembentukan karakter siswa juga diprediksi mengalami penurunan sebesar 0,299\% dengan anggapan variabel lingkungan sekolah $\left(\mathrm{X}_{2}\right)$ tetap.

Selanjutnya, setiap kenaikan $1 \%$ variabel lingkungan sekolah akan 
meningkatkan karakter siswa sebesar 0,449\%, serta sebaliknya jika lingkungan sekolah menurun sebesar $1 \%$ maka pembentukan karakter siswa diprediksi mengalami penurunan sebesar $0,449 \%$ dengan anggapan full day school $\left(\mathrm{X}_{1}\right)$ tetap.

Uji t (Parsial)

\section{Uji Hipotesis $1 \quad\left(\mathrm{Ha}_{1}\right)$,} berdasarkan tabel Coefficients diketahui nilai Sig. untuk kontribusi full day school $\left(\mathrm{X}_{1}\right)$ terhadap karakter siswa $(\mathrm{Y})$ adalah sebesar 0,003 dan nilai t hitung 3,013. Sehingga dapat disimpulkan nilai Sig. $0,003<0,005$ dan nilai t hitung 3,013> $1,983 \mathrm{t}$ tabel, maka hipotesis nol $\left(\mathrm{H}_{0}\right)$ ditolak dan hipotesis pertama $\left(\mathrm{Ha}_{1}\right)$ ini diterima yang berarti ada kontribusi positif antara full day school $\left(\mathrm{X}_{1}\right)$ dan karakter siswa (Y). Uji Hipotesis 2 $\left(\boldsymbol{H a}_{2}\right)$, berdasarkan tabel Coefficients diketahui nilai Sig. untuk Kontribusi lingkungan sekolah $\left(\mathrm{X}_{2}\right)$ terhadap karakter siswa (Y) adalah sebesar 0,000 dan nilai t hitung 4,554. Sehingga dapat disimpulkan nilai Sig. 0,000 $<0,005$ dan nilai t hitung 4,554 > 1,983 t tabel, maka hipotesis nol $\left(\mathrm{H}_{0}\right)$ ditolak dan hipotesis kedua $\left(\mathrm{Ha}_{2}\right)$ ini diterima yang berarti ada kontribusi positif antara lingkungan sekolah $\left(\mathrm{X}_{2}\right)$ dan karakter siswa $(\mathrm{Y})$.

Tabel 6. Uji F (Simultan)

\begin{tabular}{llrrrrr}
\hline \multicolumn{7}{c}{ ANOVA $^{\mathbf{b}}$} \\
\hline \multicolumn{1}{l}{ Model } & Sum of Squares & df & Mean Square & F & Sig. \\
\hline \multirow{2}{*}{1} & Regression & 1883,407 & 2 & 941,704 & 57,429 &, $000^{\mathbf{a}}$ \\
\cline { 2 - 7 } & Residual & 1672,554 & 102 & 16,398 & & \\
\cline { 2 - 6 } & Total & 3555,962 & 104 & & \\
\hline \\
a. Predictors: (Constant), Lingkungan Sekolah (X2), Full Day School (X1) \\
b. Dependent Variable: Karakter Siswa (Y)
\end{tabular}

Berdasarkan ANOVA di atas diketahui nilai signifikansi untuk kontribusi full day school $\left(\mathrm{X}_{1}\right)$ dan lingkungan sekolah $\left(\mathrm{X}_{2}\right)$ secara simultan terhadap variabel karakter siswa (Y) adalah sebesar 0,000 dan nilai $F$ hitung sebesar 57,429. Sehingga dapat disimpulkan bahwa nilai Sig. 0,000 < 0,005 dan nilai f hitung 57,429 > 3,08 f tabel, maka hipotesis nol $\left(\mathrm{H}_{0}\right)$ ditolak dan hipotesis alternatif ketiga $\left(\mathrm{Ha}_{3}\right)$ ini diterima yang berarti ada kontribusi positif secara simultan antara full day school $\left(\mathrm{X}_{1}\right)$ dan lingkungan sekolah $\left(\mathrm{X}_{2}\right)$ terhadap karakter siswa (Y).

\section{Koefisien Determinasi}

Tujuan koefisien determinasi adalah untuk melihat kemampuan variabel independen dalam menerangkan variabel dependen dan proporsi variasi dari variabel dependen yang diterangkan oleh variasi dari variabel independennya.

Table 7. Koefisien Determinasi

\begin{tabular}{|c|c|c|c|}
\hline \multicolumn{4}{|c|}{ Model Summary } \\
\hline Model & $\mathrm{R}$ & $\begin{array}{l}\text { Adjusted R } \\
\text { Square }\end{array}$ & $\begin{array}{l}\text { Std. Error of the } \\
\text { Estimate }\end{array}$ \\
\hline 1 &, $728^{a}$ &, 520 & 4,049 \\
\hline
\end{tabular}


Berdasarkan output tabel Model Summary di atas, diketahui nilai $\mathrm{R}$ Square sebesar 0,530 atau sebesar 53\%. Hal ini mengandung arti bahwa sumbangan Kontribusi penerapan full day school (X1) dan lingkungan sekolah (X2) secara simultan untuk pembentukan karakter siswa (Y) yaitu sebesar 53\% dikategorikan cukup tinggi. Dan selebihnya sebanyak $47 \%$ diKontribusii oleh faktor lain di luar variabel penelitian.

\section{PEMBAHASAN}

Kontribusi Penerapan Full Day School Terhadap Pembentukan Karakter Siswa di Sekolah Dasar (SD) Se-Kota Sungai Penuh

Berdasarkan output penelitian dapat diketahui dari uji $\mathrm{T}$ bahwa nilai Sig. untuk kontribusi full day school $\left(\mathrm{X}_{1}\right)$ terhadap karakter siswa (Y) adalah sebesar 0,003 dan nilai t hitung sebesar 3,013 . Sehingga dapat disimpulkan nilai Sig. 0,003 < 0,005 dan nilai t hitung $3,013>1,983 \mathrm{t}$ tabel, maka hipotesis nol $\left(\mathrm{H}_{0}\right)$ ditolak dan hipotesis pertama $\left(\mathrm{Ha}_{1}\right)$ ini diterima yang berarti ada Kontribusi positif antara full day school $\left(\mathrm{X}_{1}\right)$ dan karakter siswa (Y). Maka dalam penelitian ini menyatakan ada kontribusi positif antara penerapan full day school terhadap pembentukan karakter siswa di sekolah dasar (SD) swasta se-kota Sungai Penuh.

$$
\text { Menurut Arifin (2012) }
$$

menjelaskan bahwa sistem full day school merupakan ciri khas sekolah terpadu yang pembelajaran dengan sistem full day school mengharuskan sekolah merancang perencanaan pembelajaran dari pagi hingga sore serta sistem pengajaran dalam full day school yang berlangsung selama sehari penuh, mengemas seluruh program pembelajaran dan kegiatan siswa disekolah dalam sebuah sistem pendidikan yang bernuansa Islam dengan memberikan waktu tambahan untuk siswa mendalami pelajaran keagamaan.

Hal ini sesuai dengan temuan peneliti di lapangan bahwa sebelum proses pembelajaran dimulai di sekolah dasar (SD) swasta se-kota Sungai Penuh terlebih dahulu siswanya berwudhu dan setelahnya berdo'a serta membaca al qur'an bersama-sama dan dilanjutkan dengan sholat dhuha berjama'ah. Sehingaga kegiatan-kegiatan tersebut dalam penerapan full day school akan berkontribusii terhadap pembentukan karakter siswa di sekolah dasar (SD) swasta se-kota Sungai Penuh menjadi baik. Program full day school sebagaimana digambarkan di sekolah dasar (SD) swasta se-kota Sungai Penuh, potensial sebagai program dan sistem yang dapat meningkatkan karakter religius siswa asalkan titik tekan programnya adalah pada pembiasaan nilai-nilai religius.

Selanjutnya temuan peneliti ini juga sejalan dengan temuan yang dikemukakan oleh peneliti lain yaitu yaitu Raharjo, Tri Yunita, ddk (2018) hasil penelitiannya menunjukkan bahwa full day school berKontribusi secara signifikan $51,8 \%$ terhadap pembentukan karakter religius siswa kelas V SD Nasima Semarang.

Berdasarkan uraian di atas maka terdapat keterkaitan atau kontribusi penerapan full day school terhadap pembentukan karakter siswa. Artinya kualitas sistem dan program full day school di sekolah dasar (SD) swasta sekota Sungai Penuh memberikan kontribusi terhadap kualitas pembentukan karakter siswa di sekolah dasar (SD) swasta se-kota Sungai Penuh.

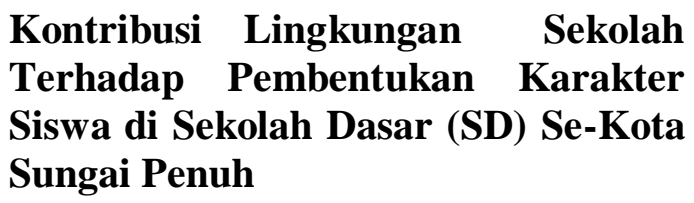


Berdasarkan output penelitian dapat diketahui dari uji $\mathrm{T}$ bahwa nilai Sig. untuk Kontribusi lingkungan sekolah $\left(\mathrm{X}_{2}\right)$ terhadap karakter siswa $(\mathrm{Y})$ adalah sebesar 0,000 dan nilai t hitung 4,554. Sehingga dapat disimpulkan nilai Sig. $0,000<0,005$ dan nilai $t$ hitung 4,554 > 1,983 t tabel, maka hipotesis nol $\left(\mathrm{H}_{0}\right)$ ditolak dan hipotesis kedua $\left(\mathrm{Ha}_{2}\right)$ ini diterima yang berarti ada Kontribusi positif antara lingkungan sekolah $\left(\mathrm{X}_{2}\right)$ dan karakter siswa (Y). Maka dalam penelitian ini menyatakan ada Kontribusi positif antara lingkungan sekolah terhadap pembentukan karakter siswa di sekolah dasar (SD) swasta sekota Sungai Penuh.

Dengan adanya lingkungan sekolah dan kontribusinya terhadap pembentukan karakter siswa ternyata mempunyai dampak positif terhadap siswa di sekolah dasar (SD) swasta sekota Sungai Penuh. Menurut Dalyono (2010) lingkungan sekolah merupakan salah satu faktor yang turut berkontribusii pertumbuhan dan perkembangan anak terutama untuk kecerdasannya, dan juga ingkungan sekolah sangat berperan dalam meningkatkan pola pikir anak, karena kelengkapan sarana dan prasarana dalam belajar serta kondisi lingkungan yang baik sangat penting guna mendukung terciptanya lingkungan belajar yang menyenangkan. Selain itu menurut Sukmadinata (2011) lingkungan sekolah terdiri dari: (a). Lingkungan fisik sekolah seperti sarana dan prasarana belajar, sumber-sumber belajar, dan media belajar. (b). Lingkungan sosial menyangkut hubungan siswa dengan teman-temanya, guru-gurunya, dan staf sekolah yang lain. (c). Lingkungan Akademis yaitu suasana sekolah dan pelaksanaan kegiatan belajar mengajar \& berbagai kegiatan kokurikuler.

Temuan penelitian ini juga
sejalan dengan penelitian yang dikemukakan oleh peneliti lain yaitu Manurung (2018), hasil penelitiannya menunjukkan bahwa terdapat Kontribusi signifikan lingkungan sekolah terhadap karakter siswa dengan koefisien determinasi sebesar $63,9 \%$ sumbangan pengharuh lingkungan sekolah terhadap karakter siswa di SMP Gajah Mada Bandar Lampung.

Berdasarkan uraian di atas maka terdapat keterkaitan atau kontribusi lingkungan sekolah terhadap pembentukan karakter siswa. Artinya kualitas lingkungan sekolah di sekolah dasar (SD) swasta se-kota Sungai Penuh memberikan kontribusi terhadap kualitas pembentukan karakter siswa di sekolah dasar (SD) swasta se-kota Sungai Penuh.

\section{Kontribusi Penerapan Full Day School dan Lingkungan Sekolah Terhadap Pembentukan Karakter Siswa di Sekolah Dasar (SD) Se-Kota Sungai Penuh}

Berdasarkan output penelitian dapat diketahui dari uji $\mathrm{F}$ bahwa nilai signifikansi untuk Kontribusi full day school $\left(\mathrm{X}_{1}\right)$ dan lingkungan sekolah $\left(\mathrm{X}_{2}\right)$ secara simultan terhadap variabel karakter siswa (Y) adalah sebesar 0,000 dan nilai $\mathrm{F}$ hitung sebesar 57,429. Sehingga dapat disimpulkan bahwa nilai Sig. $0,000<0,005$ dan nilai $\mathrm{f}$ hitung $57,429>3,08 \mathrm{f}$ tabel, maka hipotesis nol $\left(\mathrm{H}_{0}\right)$ ditolak dan hipotesis alternatif ketiga ( $\left.\mathrm{Ha}_{3}\right)$ ini diterima yang berarti ada Kontribusi positif secara simultan antara full day school $\left(\mathrm{X}_{1}\right)$ dan lingkungan sekolah $\left(\mathrm{X}_{2}\right)$ terhadap karakter siswa (Y).

Dari hasil penelitian dan pengujian hipotesis secara simultan menunjukkan ada kontribusi positif antara penerapan full day school dan lingkungan sekolah secara simultan terhadap pembentukan karakter siswa di sekolah dasar (SD) swasta se-kota Sungai Penuh dengan koefisien 
determinasinya sebesar 0,530 . Hal ini berarti bahwa pembentukan karakter siswa sekolah dasar (SD) swasta se-kota Sungai Penuh dapat ditentukan oleh variabel penerapan full day school dan lingkungan sekolah secara simultan dengan sumbangan Kontribusi sebesar 53\%. Sedangkan sisanya sebesar $47 \%$ lagi pembentukan karakter siswa ditentukan oleh faktor lain di luar variabel dalam model penelitian ini. Jadi penerapan full day school dan lingkungan sekolah secara simultan mempunyai Kontribusi positif terhadap pembentukan karakter siswa di sekolah dasar (SD) swasta se-kota Sungai Penuh yaitu Kontribusinya sebesar 53\% dikategorikan cukup tinggi.

Dari hasil analisis regresi berganda dalam peneltian ini didapatkan bilangan constan sebesar 15,180, artinya jika tidak ada full day school dan lingkungan sekolah maka karakter siswa sebesar $15,18 \%$. Nilai koefisien regresi full day school $\left(b_{1}\right)$ yaitu sebesar 0,299, dan nilai koefisien lingkungan sekolah $\left(b_{2}\right)$ sebesar 0,449. Maka persamaan regresi berganda pada penelitian ini yaitu $Y=15,180+0,299 X_{1}+0,449 X_{2}$.

Dari hasil tersebut dapat membuktikan bahwa penerapan full day school dan lingkungan sekolah dikatakan baik bila mampu membawa peningkatan dan perubahan sikap dan perilaku siswa ke arah yang positif. Dalam penelitian ini pembentukan karakter siswa berkaitan dengan perencanaan, pelaksanaan proses pembelajaran di sekolah dengan sistem dan metodenya yang baik untuk mencapai tujuan dan visi misi organisasi sekolah. Pembelajaran yang dilakukan pada full day school dapat membuat waktu anak banyak terlibat dalam kelas yang bermuara pada produktifitas yang tinggi dan siswa juga menunjukkan sikap yang lebih positif dan terhindar dari penyimpangan-penyimpangan karena keseharian berada di dalam sekolah dan dalam pengawasan guru, selain itu dengan adanya sistem pembelajaran fullday school ini bukan hanya sekedar belajar tentang akademik saja akan tetapi, belajar juga tentang non akademik atau ekstrakulikuler serta lebih menekankan pada kegiatan regiusitas siswa sehingga pelajar tidak merasa bosan dan jenuh ketika seharian berada disekolah. Selanjutnya dalam kaitan lingkungan sekolah harus memperhatikan dari segi metode belajar yang baik, hubungan guru dengan guru yang baik, hubungan siswa dengan siswa yang baik, disiplin sekolah yang baik serta sarana prasarana yang lengakap, maka jika itu terlaksana akan memberi dampak positif terhadap karakter siswa di sekolah dasar (SD) swasta se-kota Sungai Penuh.

Apabila penerapan full day school dan lingkungan sekolah semakin baik maka akan semakin meningkatkan kualitas pembentukan karakter siswa di sekolah dasar (SD) swasta se-kota Sungai Penuh, dan sebaliknya jika penerapan full day school dan lingkungan sekolah kurang baik maka kualitas pembentukan karakter siswa di sekolah dasar (SD) swasta se-kota Sungai Penuh akan semakin rendah pula.

\section{KESIMPULAN}

Berdasarkan hasil penelitian dan pembahasan maka dapat disimpulkan bahwa penerapan full day school, lingkungan sekolah, dan pembentukan karakter siswa di sekolah dasar (SD) swasta se-kota Sungai Penuh termasuk dalam kategori "Sangat Baik". Dengan rata-rata skor total setiap variabel yaitu, full day school rata-rata skor totalnya sebesar 452,7, lingkungan sekolah ratarata skor totalnya sebesar 444,5 , dan pembentukan karakter rata-rata skor totalnya sebesar 453,4 . 
Selanjutnya juga terdapat kontribusi yang positif antara variabel bebas tehadap variabel terikatnya baik secara parsial maupun secara simultan, yaitu pertama, ada kontribusi positif antara penerapan full day school terhadap pembentukan karakter siswa di sekolah dasar (SD) swasta se-kota Sungai Penuh dengan nilai Sig. 0,003 < 0,005 dan nilai t hitung 3,013>1,983 t tabel. Kedua, ada kontribusi positif antara lingkungan sekolah terhadap pembentukan karakter siswa di sekolah dasar (SD) swasta se-kota Sungai Penuh dengan nilai Sig. $0,000<0,005$ dan nilai t hitung 4,554 >1,983 t tabel. Dan ketiga, ada kontribusi positif sebesar 53\% yang termasuk kategori kontribusi cukup kuat antara penerapan full day school dan lingkungan sekolah secara simultan terhadap pembentukan karakter siswa di sekolah dasar (SD) swasta se-kota Sungai Penuh serta nilai Sig. 0,000 < 0,005 dan nilai f hitung 57,429>3,08 f tabel.

\section{REFERENSI}

Arifin, Z. (2012). Pengembangan Manajemen Mutu Kurikulum Pendidikan Islam. Jogjakara: Diva Press.

Bungin, Burhan. (2013). Metodologi Penelitian Kuantitatif: Komunikasi, Ekonomi, dan Kebijakan Publik Serta Ilmuilmu Sosial Lainnya.

Creswell, John W. (2012). Research Design Pendekatan Kualitatif, Kuantitatif, dan Mixed. Yogyakarta: Pustaka Pelajar.

Dalyono, M. (2010). Psikologi

Pendidikan. Jakarta: Rineka Cipta.
Lickona, Thomas. (2013). Character Matters (terjemahan: persoalan karakter). Jakarta: Bumi Aksara.

Manurung, Dewi Junita (2018). Pengaruh Budaya Sekolah dan Lingkungan Sekolah terhadap Pembentukan Karakter Siswa di SMP Gajah Mada Bandar Lampung. Jurnal Kultur Demokrasi. Volume 5 Nomor 12.

Martono, nanang. (2012). Metode Penelitian Kuantitatif: Analisis Isi dan Analisis Data Sekunder. Jakarta: Rajawali Pers.

Mulyasa, E. (2016). Manajemen Pendidikan Karakter. Jakarta: Bumi Aksara, cet. kelima.

Raharjo, Yunita, dkk. (2018). Pengaruh Full Day School Terhadap Pembentukan Karakter Religius Siswa di Sd Nasima Semarang. Jurnal. Dalam http://journal.unnes.ac.id/ sju/index.php/jktp

Ramdhani, Muhammad Ali. (2014). Lingkungan Pendidikan dan Implementasi Pendidikan Karakter. Jurnal Pendidikan Universitas Garut.

Sugiyono. (2017). Metode Penelitian Kuantitatif, Kualitatif, dan $R \& D . \quad$ Bandung: Alfabeta.

Sukmadinata, Nana Syaodih. (2011), Landasan Psikologi Proses Pendidikan, Bandung: Remaja Rosda Karya.

Suyyinah. (2019). Full Day Education: Konsep dan Implementasi. 
PEDAGOGIKA

Volume 11 (Nomor 2) 2020

HaL. 74-90

Malang: CV Literasi Nusantara Abadi. Cet. Kesatu.

Peraturan Presiden Republik Indonesia Nomor 87 Tahun 2017, Tentang Penguatan Pendidikan Karakter

Undang-undang Republik Indonesia Nomor 20 Tahun 2003. Tentang Sistem Pendidikan Nasional. Jakarta: Sinar Grafika. 2007.

Peraturan Menteri Pendidikan dan Kebudayaan Republik Indonesia Nomor 20 Tahun 2018, Tentang Penguatan Pendidikan Karakter Pada Satuan Pendidikan Formal

Peraturan Menteri Pendidikan dan Kebudayaan Republik Indonesia Nomor 23 Tahun 2017, Tentang Hari Sekolah 